A multibiomarker approach in the clam Ruditapes decussatus to assess the impact of pollution in the Ria Formosa lagoon, South Coast of Portugal

A. Cravo a, C. Pereira a, T. Gomes a, C. Cardoso a, A. Serafim a, C. Almeida a, T. Rocha a, b, B. Lopes a,

R. Company a, A. Medeiros a, R. Norberto a, R. Pereira a, O. Araújo a, M.J. Bebianno a, * 


\title{
A multibiomarker approach in the clam Ruditapes decussatus to assess the impact of pollution in the Ria Formosa lagoon, South Coast of Portugal
}

\author{
A. Cravo a, C. Pereira a, T. Gomes a, C. Cardoso a, A. Serafim a, C. Almeida a, T. Rocha a, b, B. Lopes a, \\ R. Company a, A. Medeiros a, R. Norberto a, R. Pereira a, O. Araújo a, M.J. Bebianno a, *
}

'CIMA e Centre for Marine and Environmental Research, Faculty of Sciences and Technology (FCT), University of Algarve, Campus de Gambelas, 8005-139 Faro, Portugal Luaboratório de Comportamento Celular, Departamento de Morfologia, Instituto de Ciências Biológicas IV, Campus II, Universidade Federal de Goiás, Caixa Postal 131, 74001-970 Goiânia, Goiás, Brasil

Keywords:

Ruditapes decussatus

Ria Formosa lagoon

Environmental monitoring
Multibiomarker approach abstract

The Ria Formosa lagoon is an ecosystem whose water quality reflects the anthropogenic influence upon the surrounding areas. In this lagoon, the clam Ruditapes decussatus has a great economical importance and has been widely used as a biomonitor. A multibiomarker approach ( $\mathrm{d}$-aminolevulinic acid dehydratase, metallothionein, lipid peroxidation, acetylcholinesterase, alkali-labile phosphates, DNA damage) was applied to assess the environmental quality of this ecosystem and the accumulation of contaminants and their potential adverse effects on clams. Clams were sampled in different shellfish beds in the period between July 2007 and December 2008 and abiotic parameters (temperature, salinity, $\mathrm{pH}$ and dissolved oxygen of seawater and organic matter in the sediment), condition index, metals ( $\mathrm{Cd}, \mathrm{Cu}, \mathrm{Zn}, \mathrm{Ni}, \mathrm{Pb}$ ), TBTs and PAHs concentrations were measured in clam tissues. Data was integrated using Principal Component Analyses and biomarker indices: IBR (Integrated Biomarker Response) and HSI (Health Status Index). This multibiomarker approach enabled discrimination of a time and space trend between sites with different degrees of anthropogenic contamination, identifying one of them (site 2) as the most stressful and summer months as the most critical period for clams due to an increase of environmental stress (anthropogenic pressure along with extreme environmental conditions, e.g. temperature, dissolved oxygen, organic matter in the sediments, etc). The selected biomarkers provided an integrated response to assess the environmental quality of the system, proving to be a useful approach when complex mixtures of contaminants occur.

\section{Introduction}

Marine ecosystems hold high ecological and economic importance since they support vital habitats for organisms and sustain several anthropogenic pressures. Highly productive areas such as estuaries and coastal lagoons are among the most extensively modified and threatened ecosystems mainly due to urban development, industrialization and tourism. As a result, complex mixtures of contaminants are continuously released to these systems deteriorating the water quality and imposing severe restrictions to organisms and possibly causing a decrease in natural resources (Cajaraville et al., 2000; Cravo et al., 2009; Monserrat et al., 2007). Such an example is the Ria Formosa lagoon, a major coastal lagoon in the
Portuguese south coast particularly important for tourism and fisheries, especially shellfish (Bebianno et al., 2007). The contaminants already known to be present in water, sediments and biota from specific sites of the lagoon include metals (Bebianno, 1995; Bebianno and Serafim, 1998, 2003; Caetano et al., 2002; Cravo et al., 2009; Serafim and Bebianno, 2001), polycyclic aromatic hydrocarbons (PAHs) (Barreira et al., 2007a, b; Bebianno et al., 2007; Bebianno and Barreira, 2009; Cravo et al., 2009), polychlorinated biphenyls (PCBs) (Barreira et al., 2005; Bebianno et al., 2007) and organotin compounds (Coelho et al., 2002; Díez et al., 2005).

Analysis of a complete array of contaminants present in the environment is virtually impossible and does not reflect deleterious effects upon the biota. Hence, measuring changes at a biochemical, cellular and physiological level can be an effective early warning signal to assess the health of aquatic organisms and ultimately of the ecosystem (Cajaraville et al., 2000). In environmental assessment and monitoring programs bivalves have been widely used as biomonitors. They respond to pollutant exposure and clams in particular, due to their suspension feeder nature, can accumulate 
the bioavailable fraction of contaminants from water and sediments (Bebianno and Serafim, 2003; Nasci et al., 2000). The clam Ruditapes decussatus has a widespread distribution in European and Mediterranean coastal waters and a great ecological and economical importance. It is extensively produced and harvested in the Ria Formosa lagoon where clam farming represents an important economical sector (Bebianno et al., 2004; Bebianno and Serafim, 2003). However, in the last decade clam production decreased as a result of the lagoon's water quality deterioration (Barreira et al., 2007a; Bebianno, 1995; Bebianno and Serafim, 2003; Bebianno et al., 2004; Coelho et al., 2002).

The environmental quality assessment of clam populations and its habitats requires the evaluation of integrated biological effects particularly in environments where complex mixtures of contaminants are present. Field studies that include a multibiomarker approach allow measurements of the impact of several environmental stressors. This approach has been very successful with invertebrates and nowadays it is a recommended tool for environmental monitoring programs (Bebianno et al., 2004; Cravo et al., 2009; Maria et al., 2009; Porte et al., 2001; Viarengo et al., 2007). Therefore, the aim of this study was to apply a suite of biomarkers in an attempt to understand the time and space contamination trend within this ecosystem and its potential adverse effect on clams. Metallothionein (MT) levels were measured in gills and used to assess the impact of metals since their induction is regarded as an indicator of metal contamination (Bebianno and Serafim, 1998). Lead in particular inhibits the activity of the enzyme d-aminolevulinic acid dehydratase (ALAD) (Company et al., 2008) and the ecotoxicological effect of this metal was determined by measuring ALAD activity in the whole soft tissues of clams. Exposure to organophosphorus compounds, substances widely used as pesticides in agriculture, was diagnosed through the inhibition of acetylcholinesterase (AChE) activity in the gills (Bebianno et al., 2004; Cajaraville et al., 2000). Additionally, a nonspecific response associated with disruption in the lipid component of cellular membranes that reflects exposure and toxicity to pollutants was assessed through lipid peroxidation (LPO) determined in the gills (Cajaraville et al., 2000; Viarengo et al., 2007). Genotoxic potential of contaminants was also evaluated due to their ability to interfere with DNA integrity (Steinert et al., 1998) analysing DNA damage in clam's haemolymph with the alkaline single-cell gel electrophoresis (Comet) assay. Finally, estrogenic contamination was assessed through the effect of xenoestrogens, vitellogenin induction mainly in males and immature females, applying the indirect alkali-labile phosphate (ALP) method to clam's gonads (Matozzo et al., 2008)

The use of a battery of different biomarkers enables the assessment of a variety of responses but it does not completely replace the chemical approach (Bebianno et al., 2004; Cravo et al., 2009). Therefore, in this study selected contaminants were also analyzed in clams tissues: metals (cadmium, copper, nickel, lead, zinc), Tributyltin (TBT) and PAHs (mostly associated with boat traffic). Environmental factors (biotic and abiotic such as condition index, temperature, salinity, $\mathrm{pH}$, dissolved oxygen of the water and sediment organic matter) may also influence biological responses and were incorporated in this assessment for a proper interpretation of the data.

Successful application of the biomarker approach in environmental assessment is limited without an integrated system to overcome difficulties in relating information and in categorizing sites according to pollutant-induced changes in the health status of the organisms. To address this issue biomarkers-based indices were developed that rank sampling sites according to contamination gradients (Beliaeff and Burgeot, 2002; Dagnino et al., 2007) and provide environmental managers with decision-support tools to evaluate the ecosystems "health". In this study, two different biomarker indices were used: the Integrated Biomarker Response (IBR) index (Beliaeff and Burgeot, 2002) and the Health Status Index (HSI) calculated by the expert system (Dagnino et al., 2007).

2. Materials and methods

2.1. Study area

The Ria Formosa is a highly productive mesotidal lagoon system in the South Coast of Portugal characterized by a seaward belt of dunes protecting a system of salt marshes, subtidal channels and tidal flats that interact with the surrounding oceanic waters via several inlets (Ribeiro et al., 2008). This lagoon is considered a valuable resource for tourism, salt extraction, fisheries and aquaculture, with a long tradition of bivalve harvesting $(20 \%$ of total area of the lagoon), like the clam Ruditapes decussatus. The Ria Formosa lagoon does not receive any significant freshwater input, except for a small river (Gilão, with a drainage area of w230 km2, with $56 \mathrm{~km}$ long, discharging close to the city of Tavira, about w25 km from the study area), having several point and diffuse pollution sources from domestic and industrial discharges, aquaculture effluents, agriculture drainages and boat traffic. The present study was undertaken at the middle region of the lagoon, in the most important shellfish bed area within this ecosystem, which accommodates one the major fishing harbours in the South Coast of Portugal. This area is known to be affected by contaminants due to intensive boat traffic and magnitude of fish products in an area of reduced hydrodynamic conditions (Bebianno et al., 2007; Coelho et al., 2002; Cravo et al., 2009; Maria et al., 2009).

2.2. Sampling

Clams (33.41 $Æ 1.5 \mathrm{~mm}$ ) were collected in a monthly basis, from July 2007 to December 2008, in four shellfish beds selected according to different environmental characteristics (Fig. 1), around low tide, in the morning period ( $9 \mathrm{e} 11 \mathrm{~h})$. Site 1 (S1) is located near a Sewage Treatment Plant (STP, z250 m) that serves a population of w45 000 equivalent inhabitants; site 2 (S2) is in one of the main inner channels; site 3 (S3) is in front of the fishing harbour and recreational pier; and site 4 (S4) is in one of the main channels, closer to the major inlet.

The physical-chemical characterization of the water was carried out in situ by measuring temperature, salinity, $\mathrm{pH}$, and \% oxygen saturation with a multiparametric probe YSI 6600. Sediment organic content was determined in 3 random replicates of the surface sediment layer $(\mathrm{z} 5 \mathrm{~cm})$ for each shellfish bed as the percentage of weight loss by combustion at $450 \mathrm{C}$ for $4 \mathrm{~h}$ after achieving constant weight by drying at $100 \mathrm{C}$ for $24 \mathrm{~h}$. Clams were collected ( $\mathrm{n}$ z 100 in each shellfish bed) for chemical and biomarker analysis, transported alive to the laboratory in cold containers (w4 C). For metals, TBT and PAHs analysis, clams were collected in July and October of 2007 and in July, October and December of 2008. Additionally, in the summer of 2008 clams were also collected monthly for metals analysis and depurated for a period of $48 \mathrm{~h}$ and stored at À20 C. Contaminants were determined in the whole soft tissues. For biochemical analyses clams were collected monthly and total soft tissues, gills and gonads were separated and haemolymph collected, and immediately frozen in liquid nitrogen and stored at À80 C until further use. 


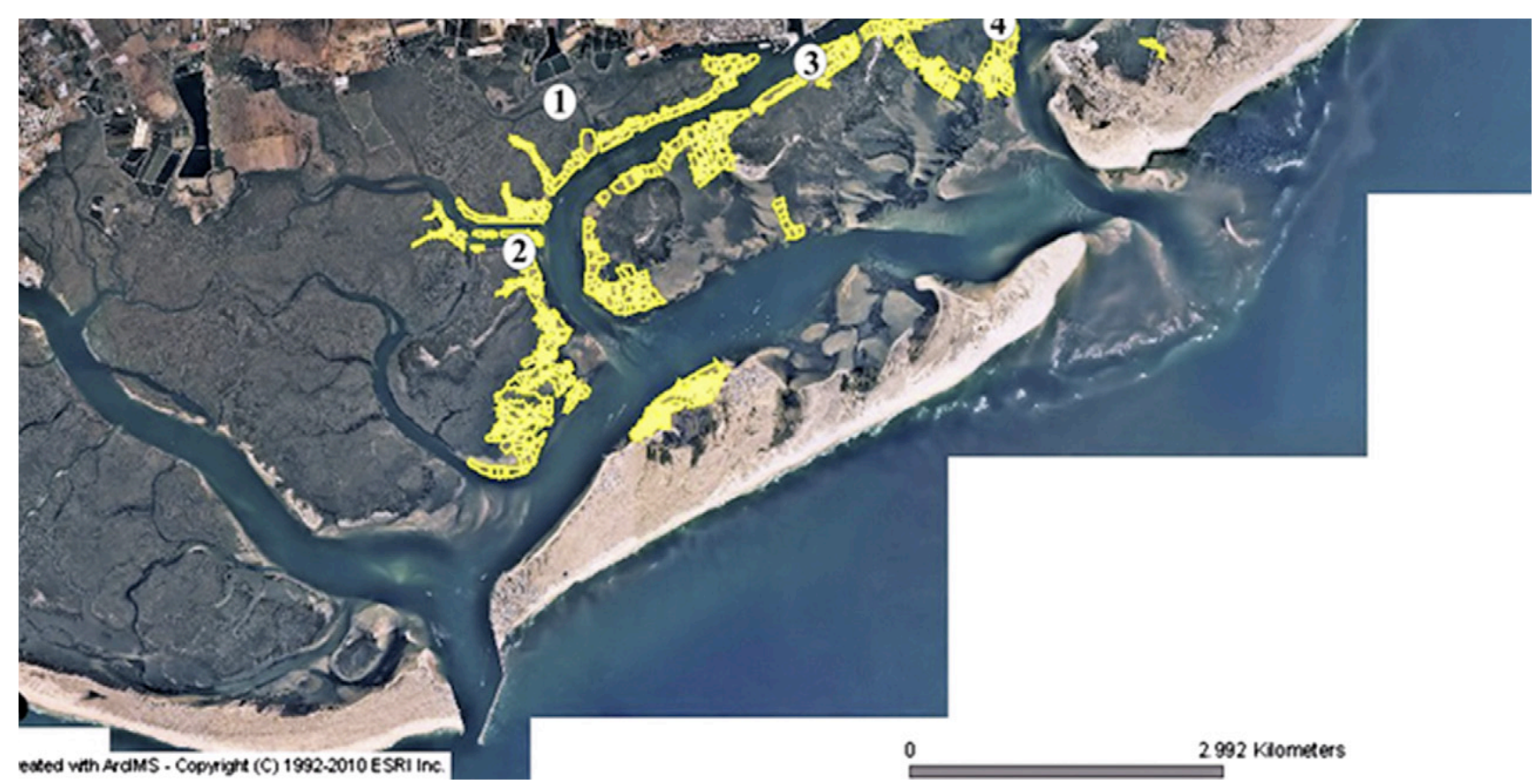

Fig. 1. Sampling sites within the Ria Formosa lagoon. Adapted from: http://www.icn.pt/website/viveiros/viewer.htm. Markings represent shellfish bed areas.

clams (w1 g of dried tissue, $n \frac{1}{4}$ 5). Samples were wet digested with nitric acid ( $\left.\mathrm{HNO}_{3}\right)$ and analysed by atomic absorption spectrophotometry (AAS AAnalyst 800 - Perkin Elmer). Quality assurance was checked using a standard reference material (Lobster Hepatopancreas) provided by the National Research Council, Canada e TORT II. The values (mean $Æ$ standard deviation) obtained were

$27.2 Æ 0.9 \mathrm{mg}$ gÀ 1 for $\mathrm{Cd}, 106.5 \nRightarrow 1.8 \mathrm{mg}$ gÀ 1 for $\mathrm{Cu}, 2.3 \approx 0.1 \mathrm{mg}$ gÀ1 for $\mathrm{Ni}, 0.3 Æ 0.02 \mathrm{mg}$ gÀ 1 for $\mathrm{Pb}$ and $193.7 Æ 7.1 \mathrm{mg}$ gÀ 1 for $\mathrm{Zn}$ compared with the certificated values of $26.7 \approx 0.6 \mathrm{mg}$ gÀ1, $106.0 Æ 10.0 \mathrm{mg}$ gÀ1, 2.5 Æ $0.2 \mathrm{mg}$ gÀ1, 0.4 Æ $0.1 \mathrm{mg}$ gÀ 1 and 180.0 Æ $6.0 \mathrm{mg}$ gÀ 1 , respectively. All metal concentrations are expressed as mg per g of dry weight.

\subsubsection{TBT analysis}

Tributyltin (TBT) was measured in the whole soft tissue of clams (n $1 / 4$ 5) by atomic absorption spectrophotometry (AAS AAnalyst 800 - Perkin Elmer), as described by Bryan et al. (1986) and Langston et al. (1987) and expressed as mg gà1 dry weight. Quality assurance was checked using a standard reference material (CMR477, Tributyltin in mussel tissue). The value (mean $Æ$ standard deviation) obtained was $2.0 Æ 0.1 \mathrm{mg}$ gà1 of TBT $\left(\mathrm{Sn}\left(\mathrm{C}_{4} \mathrm{H} 9\right)_{3}\right)$ compared to the certified value of $2.2 Æ 0.2 \mathrm{mg}$ gÀ1 of TBT.

\subsubsection{PAHs analysis}

Polycyclic Aromatic Hydrocarbons (PAHs) were identified and quantified in clams whole soft tissues ( $n^{1 / 4}$ ) by HPLC-UV and expressed as ng gÀ 1 dry weight. A standard containing 16 individual PAHs (EPA 610 PAH mix, Sigma) was used, as described in Cravo et al. (2009), with a detection limit from 0.01 to 0.04 ng gà 1 dry weigh for each individual PAH. Measurements were validated using a standard reference material of mussel tissue (SRM 2977; NIST, USA) with recoveries between 73 and $112 \%$.

\subsection{Condition index (CI)}

To assess the physiological state of the organisms, the soft tissues and shells of fifteen clams were weighted and the condition index (CI) was estimated as a percentage of the ratio between the dry weight of the soft tissues ( $\mathrm{g}$ ) and the dry weight of the shell (g) (Moschino and Marin, 2006). Dry weight of soft tissues and shells were obtained at $80 \mathrm{C}$, during a maximum period of $24 \mathrm{~h}$, until reaching constant weight.

\subsection{Biochemical analysis}

2.5.1. Metallothionein (MT)

Metallothionein (MT) concentrations were determined in gills of R. decussatus ( $n^{1 / 4}$ ) according to the method developed by Bebianno and Langston (1989) and detailed in Cravo et al. (2009) MT concentrations are expressed as a milligram per gram of total protein concentration.

2.5.2. d-Aminolevulinic acid dehydratase (ALAD)

$\mathrm{d}$-aminolevulinic acid dehydratase (ALAD) activity (EC 4.2.1.24) was determined in the whole soft tissues of clams ( $\mathrm{n} 1 / 45$ ) according to the European standardized method for d-ALAD activity determination in blood (Berlin and Schaller, 1974) and expressed as ng of porphobilinogen (PBG) per min per mg of total protein. The methodology is fully described in Cravo et al. (2009).

2.5.3. Acetylcholinesterase (AChE)

Acetylcholinesterase (AChE) activity was determined in the gills of clams ( $\mathrm{n} 1 / 45$ ), according to the colorimetric method of Ellman et al. (1961) and described in Cravo et al. (2009). This method is based on the coupled enzyme reaction of acetylthiocholine as the specific substrate for AChE and 5,50 -dithio-bis-2-nitrobenzoate as an indicator for the enzyme reaction at $450 \mathrm{~nm}$. AChE activity is expressed in nmol per min per mg of total protein.

2.5.4. Lipid peroxidation (LPO)

Lipid peroxidation (LPO) was determined in the same gill samples used for MT determination according to the method developed by Erdelmeier et al. (1998), described in Cravo et al. 
(2009) and expressed as nmol MDA and 4-HNE per g of total protein.

\subsubsection{DNA damage}

DNA damage was detected according to the Comet assay, in haemocytes collected from the posterior adductor muscle of clams (n $1 / 4$ 10). The Comet assay applied was a slightly modified version of that previously described by Singh et al. (1988), and the Olive Tail Moment (product of comet tail length and quantity of DNA in the comet tail) was the comet parameter chosen to characterize the DNA damage.

2.5.6. Vitellogenin-like proteins

The levels of vitellogenin-like (Vg-like) proteins were determined in gonad tissues of 15 clams (separated by gender in a similar ratio) by an indirect alkali-labile phosphate method (ALP), according to Blaise et al. (1999) and described in detail in Pereira et al. (in press). Total ALP concentrations were normalized as to the total protein content of the gonad, and results are expressed as mg of phosphate per mg of total protein concentration.

\subsection{Total protein concentrations}

Total protein content of clam gills and total tissues was measured by the Lowry method (Lowry et al., 1951) using Folin's Reagent. For the ALP assay, the total proteins were determined by the Bradford method (Bradford, 1976). In both cases Bovine Serum Albumin (BSA) was used as reference standard.

\subsection{Statistical analysis}

All data was tested for normality and homogeneity of variance. One-way analysis of variance (ANOVA) or KruskaleWallis One Way Analysis of Variance on Ranks was applied to detect significant differences between sites. If significant, pairwise multiplecomparison procedures were conducted using the Tukey or the Dunn's tests. Pearson's correlation analysis was performed to verify existing relationships between biomarkers, contaminants and environmental parameters. Additionally, Principal Component Analysis (PCA) was also applied to the mean values from the 4 sites to evaluate the relationships between variables. To discriminate the differences between months with higher environmental stress among the two years of sampling another PCA analysis was conducted. Statistical significance was defined at $p<0.05$, and analysis was performed with XLStat2009ò.

\subsection{Biomarker indices}

The Integrated Biomarker Response (IBR) was applied for each site, combining the biomarkers responses in clam tissues (MT, ALAD, AChE, LPO, DNA damage and ALP in males and females) following the method described by Beliaeff and Burgeot (2002). To contribute also to a decision-support tool or expert system capable of integrating the selected biomarkers battery in the five-level Health Status Index

Ranks and corresponding to colour codes for the ecological quality indices applied to the sites within the Ria Formosa Lagoon.

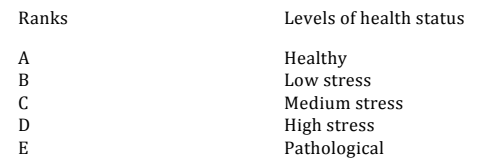

HSI) developed by Dagnino et al. (2007) was applied for each site using the DiSAV Expert System (DES). The results of both indices obtained for each site were adapted to a colour code (Table 1) to match the Ecological index established by the European Union Water Framework Directive (Directive, 2000/60/EC).

3. Results

3.1. Environmental parameters

Water and sediment features measured at each site from July 2007 to December 2008 are in Table 2.

Table 2

Environmental parameters measured monthly in water and organic matter in December 2008. T e temperature, S e salinity, DO e dissolved oxygen, OMS e organic matter in sediment.

\begin{tabular}{|c|c|c|c|c|c|c|}
\hline Sites & Month & $\mathrm{T}(\mathrm{C})$ & S & $\mathrm{pH}$ & Do (\%) & OMS (\%) \\
\hline \multirow[t]{13}{*}{1} & Jul 07 & 24.3 & 36.5 & 8.1 & 112 & 2.0 \\
\hline & Aug 07 & 23.0 & 36.1 & 7.8 & 50 & 2.2 \\
\hline & Sep 07 & 22.8 & 37.0 & 7.5 & 67 & 1.2 \\
\hline & Oct 07 & 21.5 & 36.8 & 7.7 & 131 & 1.6 \\
\hline & Apr 08 & 17.8 & 34.9 & 7.8 & 74 & 2.1 \\
\hline & Jun 08 & 22.9 & 36.6 & 7.7 & 76 & 2.1 \\
\hline & Jul 08 & 27.5 & 37.0 & 8.4 & 139 & 1.5 \\
\hline & Aug 08 & 22.5 & 37.6 & 8.1 & 98 & 2.7 \\
\hline & Sep 08 & 21.0 & 36.5 & 7.7 & 95 & 2.0 \\
\hline & Oct 08 & 22.0 & 35.4 & 7.8 & 88 & 1.2 \\
\hline & Nov 08 & 16.6 & 36.1 & 7.9 & 94 & 1.9 \\
\hline & Dec 08 & 13.1 & 35.6 & 7.8 & 99 & 2.2 \\
\hline & Mean $Æ$ std & $21.3 \nRightarrow 4.0$ & $36.3 Æ 0.9$ & $7.9 Æ 0.3$ & $93 \nRightarrow 29$ & $1.9 \mathrm{E}$ \\
\hline
\end{tabular}

$\begin{array}{llllll}\text { Jul 07 } & 26.7 & 36.8 & 8.3 & 160 & 0.8 \\ \text { Aug 07 } & 25.5 & 35.9 & 8.5 & 71 & 0.8 \\ \text { Sep 07 } & 24.8 & 36.5 & 7.7 & 103 & 1.0 \\ \text { Oct 07 } & 22.6 & 36.6 & 8.3 & 113 & 0.8 \\ \text { Apr 08 } & 19.5 & 36.1 & 8.2 & 126 & 1.0 \\ \text { Jul 08 } & 25.5 & 36.1 & 8.6 & 182 & 1.2 \\ \text { Aug 08 } & 22.6 & 36.1 & 8.5 & 139 & 0.9 \\ \text { Sep 08 } & 22.8 & 36.5 & 8.3 & 138 & 0.8 \\ \text { Nov 08 } & 14.9 & 36.5 & 7.9 & 94 & 1.0 \\ \text { Dec 08 } & 14.6 & 36.1 & 8.2 & 131 & 1.1 \\ \text { Mean Æ std } & 22.0 \text { Æ 4.4 } & 36.3 \text { Æ } 0.3 & 8.3 \approx 0.3 & 126 \text { Æ 34 } & 1.0 \text { Æ } 0.2\end{array}$

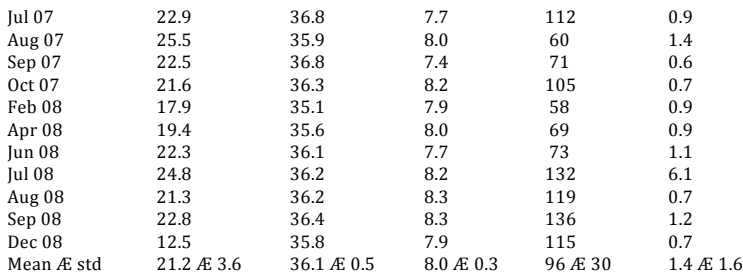

$\begin{array}{llllll}\text { Jul 07 } & 26.8 & 37.4 & 8.0 & 142 & 0.4 \\ \text { Aug 07 } & 26.2 & 36.1 & 8.6 & 76 & 4.9 \\ \text { Sep 07 } & 22.7 & 36.3 & 7.9 & 109 & 0.7 \\ \text { Oct 07 } & 21.0 & 36.8 & 8.3 & 115 & 0.9 \\ \text { Nov 07 } & 17.7 & 36.6 & 8.6 & 117 & 0.7 \\ \text { Feb 08 } & 18.1 & 34.9 & 8.2 & 67 & 0.9 \\ \text { Apr 08 } & 19.2 & 35.9 & 8.3 & 81 & 0.7 \\ \text { Jun 08 } & 22.8 & 36.2 & 7.7 & 104 & 0.8 \\ \text { Jul 08 } & 25.6 & 36.2 & 8.5 & 156 & 0.8 \\ \text { Aug 08 } & 22.3 & 35.8 & 8.5 & 126 & 0.8 \\ \text { Sep 08 } & 22.1 & 36.3 & 8.2 & 122 & 0.8 \\ \text { Oct 08 } & 18.8 & 35.7 & 7.9 & 81 & 0.9 \\ \text { Nov 08 } & 14.3 & 36.2 & 7.6 & 82 & 0.7 \\ \text { Dec 08 } & 13.3 & 36.1 & 8.0 & 118 & 0.8 \\ \text { Mean Æ std } & 20.8 \text { Æ 4.1 } & 36.2 \text { Æ } 0.1 & 8.2 \text { Æ } 0.3 & 107 \text { Æ 26 } & 1.1 \text { Æ } 1.1\end{array}$


Temperature varied markedly during the sampling period, following the typical seasonal variation pattern. The highest levels at each site were in August 2007 and July of both years, ranging from 25.5 to $27.5 \quad \mathrm{C}$ and lowest in December (12.5e14.6 C). The maximum (27.5 C) was at site 1 (July 2008), while the minimum $(12.5 \mathrm{C})$ in site 3 (December 2008). The mean water temperature (Table 2) diminished progressively from S2 ! S1 z S3 ! S4, however no significant differences exist between sites ( $p>0.05)$. Salinity ranged from 34.9 (February and April 2008) to 37.6 (August 2008). Sites 1 and 4 had the highest salinity variation in winter/spring and summer respectively. The mean salinity levels (Table 2) diminished from S1 z S2 ! S4 ! S3 and, as for temperature, there were no significant differences between sites $(\mathrm{p}<0.05)$.

The $\mathrm{pH}$ values varied slightly between sites ranging between 7.4 (September 2007) and 8.6 (August, November 2007 and July 2008), with the lowest levels in site 1 and site 3 (7.5 and 7.4, respectively) and significantly higher in sites 2 and $4(8.6)(\mathrm{p}<0.05)$. During the sampling period, the mean $\mathrm{pH}$ levels (Table 2) decreased from S2 ! S4 ! S3 ! S1, with significant differences between sites 1 and 2 , sites 1 and 4 and sites 2 and $3(\mathrm{p}<0.05)$.

The percentage of dissolved oxygen, like temperature, also varied considerably between sites and months. In August 2007 values were low (71\%) in sites 1,2 and 3 and in February 2008 in sites 3 and 4 . The highest levels ( $>120 \%)$ were in July (2007 and 2008) for sites 1, 2 and 4 and in July and September 2008 for site 3 . The mean percentage of dissolved oxygen in water (Table 2) followed the pattern S2 ! S4 ! S3 ! S1, with only significant differences between sites 1 and 2 and sites 2 and $3(p<0.05)$.
The percentage of organic matter in the sediment was $1 \%$, characteristic of sandy sediments, typical of shellfish beds areas. The highest percentage of organic matter (4.9 and 6.1\%) was detected in summer (August 2007 and July 2008) in sites 4 and 3, respectively, suggesting a higher accumulation of organic matter in the sediments. This may be responsible for the decrease in the percentage of dissolved oxygen in water (and pH due to the release of carbon dioxide). The mean percentage of organic matter (Table 2) was higher in S1 ! S3 ! S4 ! S2, only with site 1 significantly different from sites 2 and $4(\mathrm{p}<0.05)$.

\subsection{Bioaccumulation of contaminants}

Monthly and mean metal concentrations are in Table 3, while TBT and PAHs concentrations are in Table 4. Metal $(\mathrm{Cd}, \mathrm{Cu}, \mathrm{Ni}, \mathrm{Pb}$ and $\mathrm{Zn}$ ) concentrations varied, with no spatial and temporal pattern observed. However, clams from sites 1 and 2 had generally higher metal concentrations than the other sites. For $\mathrm{Pb}$, significantly highest concentrations exist in sites 2 and 4 ( $\mathrm{p}<0.05)$. However, no significant differences were found between the mean value of any metal for all the sampling sites $(p>0.05)$.

TBT concentrations ranged from 0.06 to $0.13 \mathrm{mg}$ gÀ1 d.w. Levels were significantly higher in clams from sites 3 and 4 in July (2008 and 2007 , respectively) $(\mathrm{p}<0.05)$. However, there was also an increase in December 2008 in sites 1 and 2, which could be associated to a uniform contamination of this compound throughout the year. The average TBT concentrations followed the spatial sequence: S3 ! S4 > S2 ! S1, despite only a significant difference was found between sites 1 and $3(\mathrm{p}<0.05)$.

Table 3

Metal ( $\mathrm{Cd}, \mathrm{Cu}, \mathrm{Ni}, \mathrm{Pb}$ and $\mathrm{Zn}$ ) concentrations of the total edible tissue of clams Ruditapes decussatus ( $\mathrm{n} 1 / 4 \mathrm{5}$ ) collected in sites 1 to 4 , measured every three months, between July 2007 and December 2008, expressed in a dry weight $(\mathrm{dw})$

\begin{tabular}{|c|c|c|c|c|c|c|}
\hline Site & Month & Cd (mg gà̀ dw) & $\mathrm{Cu}(\mathrm{mg} g \grave{A} 1 \mathrm{dw})$ & $\mathrm{Ni}(\mathrm{mg} g \grave{a} 1 \mathrm{dw})$ & $\mathrm{Pb}(\mathrm{mg} g \grave{1} 1 \mathrm{dw})$ & $\mathrm{Zn}(\mathrm{mg} g \dot{A} 1 \mathrm{dw})$ \\
\hline \multirow[t]{9}{*}{1} & Jul 07 & $0.2 \nRightarrow \quad 0.0$ & $9.3 Æ 1.1$ & $2.1 \nRightarrow 0.2$ & $0.4 Æ 0.1$ & $60.7 \nRightarrow 5.1$ \\
\hline & Oct 07 & $0.3 \approx \quad 0.0$ & $14.8 £ 1.8$ & $2.4 \nRightarrow 0.1$ & $0.2 £ 0.0$ & $68.3 \nRightarrow 2.6$ \\
\hline & Jun 08 & $0.1 \nRightarrow \quad 0.0$ & $8.3 £ 0.3$ & $1.9 Æ 0.1$ & $0.8 Æ 0.0$ & $52.1 \nRightarrow 3.1$ \\
\hline & Jul 08 & $0.2 Æ \quad 0.1$ & $13.6 \nRightarrow 2.4$ & $1.8 \nRightarrow 0.4$ & $1.1 \nRightarrow 0.1$ & $97.4 Æ 31.9$ \\
\hline & Ag 08 & $0.1 \nRightarrow \quad 0.0$ & $16.0 £ 4.0$ & $1.1 \nRightarrow 0.0$ & $1.2 Æ 0.2$ & $78.1 Æ 11.1$ \\
\hline & Oct 08 & $0.2 Æ \quad 0.0$ & $6.4 Æ 0.1$ & $2.8 Æ 0.2$ & $0.9 Æ 0.1$ & $65.0 \nRightarrow 3.6$ \\
\hline & Nov 08 & $0.2 Æ \quad 0.0$ & $20.0 Æ 13.1$ & $2.6 \notin 0.3$ & $1.3 Æ 0.1$ & $62.0 Æ 2.4$ \\
\hline & Dec 08 & $0.2 Æ \quad 0.0$ & $14.7 £ 3.3$ & $1.9 Æ 0.1$ & $1.0 Æ 0.1$ & $60.8 \nRightarrow 0.1$ \\
\hline & Mean $Æ$ std & $0.2 \approx \quad 0.1$ & $12.9 Æ 4.6$ & $2.1 \nRightarrow 0.6$ & $0.9 Æ 0.4$ & $68.1 \nRightarrow 14.0$ \\
\hline \multirow[t]{7}{*}{2} & Jul 07 & $0.2 \approx \quad 0.0$ & $5.3 \quad Æ 0.9$ & $1.4 Æ 0.3$ & $0.2 Æ 0.0$ & $62.9 Æ 7.9$ \\
\hline & Oct 07 & $0.3 Æ \quad 0.1$ & $11.1 Æ 0.5$ & $1.8 Æ 0.4$ & $0.3 \approx 0.0$ & $67.3 \nRightarrow 2.1$ \\
\hline & Jul 08 & $0.2 Æ \quad 0.0$ & $29.2 \nRightarrow 0.8$ & $0.7 \approx 0.2$ & $1.1 \approx 0.1$ & $80.6 \vDash 4.8$ \\
\hline & $\mathrm{Ag} 08$ & $0.3 Æ \quad 0.1$ & $11.4 Æ 3.1$ & $1.1 \nRightarrow 0.1$ & $1.1 Æ 0.1$ & $85.6 \nRightarrow 20.1$ \\
\hline & Nov 08 & $0.2 Æ \quad 0.0$ & $11.4 Æ 4.4$ & $2.3 \approx 0.2$ & $1.4 Æ 0.0$ & $72.3 \quad Æ 4.8$ \\
\hline & Dec 08 & $0.4 Æ \quad 0.5$ & $7.9 \quad Æ 2.0$ & $1.8 Æ 0.1$ & $1.2 Æ 0.1$ & $62.4 Æ 1.0$ \\
\hline & Mean $Æ$ std & $0.3 Æ \quad 0.1$ & $12.7 \quad Æ 8.5$ & $1.5 Æ 0.6$ & $0.9 Æ 0.5$ & $71.9 \approx F 9.6$ \\
\hline \multirow[t]{7}{*}{3} & Jul 07 & $0.3 \approx \quad 0.0$ & $7.0 Æ 0.4$ & $1.7 £ 0.5$ & $0.6 \nRightarrow 0.0$ & $77.3 \approx 7.2$ \\
\hline & Oct 07 & $0.2 \approx \quad 0.0$ & $7.3 Æ 0.4$ & $1.6 Æ 0.1$ & $0.3 Æ 0.1$ & $63.4 \notin 3.0$ \\
\hline & Jun 08 & $0.1 \nRightarrow \quad 0.0$ & $9.1 \nRightarrow 1.5$ & $2.1 \nRightarrow 0.2$ & $0.8 Æ 0.0$ & $86.9 \notin 9.6$ \\
\hline & Jul 08 & $0.1 \nRightarrow \quad 0.0$ & $17.2 Æ 6.8$ & $1.9 Æ 0.3$ & $1.3 Æ 0.4$ & $77.1 \nRightarrow 20.3$ \\
\hline & $\mathrm{Ag} 08$ & $0.1 \nRightarrow \quad 0.0$ & $11.4 Æ 2.0$ & $1.4 Æ 0.3$ & $0.9 \nRightarrow 0.1$ & $66.8 \nRightarrow 13.3$ \\
\hline & Sep 08 & $\begin{array}{lll}0.1 \nRightarrow & 0.0\end{array}$ & $8.7 Æ 2.4$ & $2.4 Æ 0.0$ & $0.9 Æ 0.1$ & $75.0 \approx 15.4$ \\
\hline & Mean $Æ$ std & $0.2 Æ \quad 0.1$ & $10.1 £ 3.8$ & $1.8 \nRightarrow 0.4$ & $0.8 Æ 0.3$ & $74.4 \nRightarrow 8.4$ \\
\hline \multirow[t]{10}{*}{4} & Jul 07 & $0.2 Æ \quad 0.0$ & $8.9 \quad Æ 1.1$ & $2.6 \notin 0.1$ & $0.2 Æ 0.1$ & $81.2 Æ 8.1$ \\
\hline & Oct 07 & $0.2 Æ \quad 0.0$ & $13.1 \approx 3.6$ & $2.9 Æ 0.5$ & $0.3 Æ 0.0$ & $64.5 \nRightarrow 3.2$ \\
\hline & Jun 08 & $0.1 \nRightarrow \quad 0.0$ & $8.0 \nRightarrow 2.1$ & $1.1 \nRightarrow 0.2$ & $0.9 Æ 0.0$ & $61.3 \nRightarrow 10.4$ \\
\hline & Jul 08 & $0.7 \nRightarrow \quad 0.1$ & $\begin{array}{l}0.0 \\
19.2 \approx 3.1\end{array}$ & $2.1 \nRightarrow 0.5$ & $0.9 Æ 0.1$ & $85.5 \nRightarrow 5.4$ \\
\hline & $\mathrm{Ag} 08$ & $\begin{array}{ll}0.2 Æ & 0.0\end{array}$ & $18.2 Æ 0.0$ & $2.8 \nRightarrow 0.4$ & $0.8 Æ 0.1$ & $67.0 \nRightarrow 7.4$ \\
\hline & Sep 08 & $0.2 \approx \quad 0.0$ & $7.6 \quad \nRightarrow 0.0$ & $2.0 Æ 0.5$ & $1.2 Æ 0.1$ & $60.2 \approx 6.6$ \\
\hline & Oct 08 & $0.2 Æ \quad 0.0$ & $7.3 \quad Æ 1.7$ & $2.0 Æ 0.1$ & $1.0 Æ 0.1$ & $68.7 \approx 3.3$ \\
\hline & Nov 08 & $0.2 \nRightarrow \quad 0.0$ & $20.6 \nRightarrow 0.0$ & $2.4 Æ 0.3$ & $1.4 Æ 0.1$ & $71.0 \notin 3.5$ \\
\hline & Dec 08 & $0.2 Æ \quad 0.0$ & $6.0 \quad Æ 0.4$ & $0.1 \nRightarrow 0.0$ & $1.1 \nRightarrow 0.2$ & $73.0 \vDash 1.6$ \\
\hline & Mean $Æ$ std & $\begin{array}{lll}0.2 Æ & 0.2\end{array}$ & $12.1 \nRightarrow 5.8$ & $2.0 \nRightarrow 0.9$ & $0.9 Æ 0.4$ & $70.3 \approx 8.6$ \\
\hline
\end{tabular}


Table 4

TBT and PAHs concentrations of the total edible tissue of clams Ruditapes decussatus (n $1 / 45$ ) collected in sites 1 to 4 , measured every three months, between July and October 2007 and July and December 2008. TBT e Tributyltin, tPAHs e total PAHS, \% PAHs with 2 p 3 rings 4 rings and 5 p 6 rings respectively.

\begin{tabular}{|c|c|c|c|c|c|c|c|}
\hline \multirow{3}{*}{$\begin{array}{l}\text { Site } \\
1\end{array}$} & \multirow{2}{*}{$\begin{array}{l}\text { Month } \\
\text { Jul } 07\end{array}$} & \multicolumn{2}{|c|}{$\begin{array}{l}\text { TBT } \\
(\mathrm{mg} g \hat{\mathrm{A}} 1 \mathrm{dW})\end{array}$} & $\begin{array}{l}\text { tPAHs } \\
\text { (ng gÀ1 dw) }\end{array}$ & \multirow{2}{*}{$\begin{array}{l}2 \mathrm{p} 3 \\
\text { rings (\%) } \\
30.7\end{array}$} & \multirow{2}{*}{$\begin{array}{l}4 \text { rings } \\
(\%) \\
20.7\end{array}$} & \multirow{2}{*}{$\begin{array}{l}\text { 5p6 } \\
\text { rings (\%) } \\
48.6\end{array}$} \\
\hline & & 0.07 & Æ 0.02 & $224 Æ 16$ & & & \\
\hline & Oct 07 & 0.07 & E 0.03 & $399 \quad Æ 38$ & 75.5 & 2.4 & 22.1 \\
\hline & Jul 08 & 0.06 & Æ 0.02 & 183 E 8 & 55.4 & 2.1 & 42.5 \\
\hline & Oct 08 & 0.06 & E 0.03 & 275 Æ 73 & 47.3 & 9.2 & 43.5 \\
\hline & Dec 08 & 0.09 & Æ 0.03 & $437 \approx 30$ & 60.8 & 5.2 & 33.9 \\
\hline & Mean $Æ$ std & 0.07 & Æ 0.01 & $303 \approx 127$ & $54 Æ 17$ & $8 Æ 8$ & $38 Æ 10$ \\
\hline \multirow[t]{5}{*}{2} & Jul 07 & 0.06 & Æ 0.01 & $165 Æ 8$ & 14.1 & 18.5 & 67.4 \\
\hline & Oct 07 & 0.08 & E 0.02 & $464 \approx 69$ & 29.7 & 11.3 & 59.0 \\
\hline & Jul 08 & 0.08 & Æ 0.02 & $309 \notin 4$ & 35.2 & 16.9 & 47.9 \\
\hline & Dec 08 & 0.08 & E 0.02 & $156 Æ 21$ & 38.4 & 5.5 & 56.1 \\
\hline & Mean $Æ$ std & 0.08 & E 0.01 & 274 E 155 & $29 Æ 11$ & $22 Æ 15$ & $28 \nRightarrow 16$ \\
\hline \multirow[t]{4}{*}{3} & Jul 07 & 0.08 & Æ 0.02 & $263 Æ 58$ & 24.6 & 7.2 & 68.2 \\
\hline & Oct 07 & 0.09 & Æ 0.03 & $487 \quad \& 110$ & 6.5 & 10.6 & 83.0 \\
\hline & Jul 08 & 0.13 & Æ 0.03 & $277 \quad \leftleftarrows 78$ & 36.4 & 4.8 & 58.9 \\
\hline & Mean $Æ$ std & 0.10 & Æ 0.03 & $342 \approx 113$ & $22 Æ 15$ & $8 Æ 3$ & $70 Æ 12$ \\
\hline \multirow[t]{6}{*}{4} & Jul 07 & 0.12 & $£ 0.02$ & $63 Æ_{1}$ & 2.6 & 6.6 & 90.1 \\
\hline & Oct 07 & 0.11 & Æ 0.02 & $157 \quad \approx 36$ & 28.0 & 2.9 & 69.1 \\
\hline & Jul 08 & 0.11 & Æ 0.02 & 126 \& 15 & 35.7 & 13.0 & 51.3 \\
\hline & Oct 08 & 0.06 & Æ 0.02 & $102 Æ 7$ & 47.2 & 5.0 & 47.9 \\
\hline & Dec 08 & 0.06 & Æ 0.01 & $180 \quad Æ \quad 11$ & 26.3 & 15.3 & 58.5 \\
\hline & Mean $Æ$ std & 0.09 & E 0.03 & $126 Æ 59$ & $28 \nRightarrow 16$ & $9 \notin 5$ & $63 Æ 17$ \\
\hline
\end{tabular}

PAHs concentrations ranged from 63 to 487 ng gÀ1 d.w. Globally, the average $\mathrm{PAH}$ levels showed a decreasing pattern from S3 ! S1 ! S2 > S4, with only site 4 significantly lower than the remaining sites $(\mathrm{p}<0.05)$. Although the temporal variation was not consistent for all sites, significantly highest concentrations were in sites 1, 2 and 3 (October 2007) and site 1 (December 2008) $(\mathrm{p}<0.05)$. The maximum total PAH concentrations and mean percentage of high molecular weight ( 5 p 6 rings $1 / 470 \%$ ) was detected in clams from site 3.

\subsection{Condition index}

The condition index ranged from $7 \%$ to $w 17 \%$ (Table 5 ). The highest CI in clams collected in site 4 (June 2008, 16.6\%) was significantly higher than the minimum at site 1 (November 2008, $7.0 \%)(\mathrm{p}<0.05)$. A decreasing pattern was detected in summer until November in all the four sites. The mean condition index varied as follows: S4 ! S2 ! S3 ! S1 and was not significantly different between sites ( $p>0.05)$, except for site 1 , where clams had a significantly lower mean condition index $(\mathrm{p}<0.05)$.

\subsection{Biomarkers responses}

Biomarkers (MT, ALAD, AChE, LPO, DNA damage and Vg-like proteins (ALP)) for all sites are in Table 5 .

Globally, the biomarkers responses are characterized by a high spatial and temporal variation, despite higher in summer months, i.e. JulyeOctober of both years, except ALP in immature individuals. No significant correlations exist between biomarkers and contaminants $(\mathrm{p}>0.05)$.

Considering the biomarkers individually, MT was significantly higher in August 2007 (site 3) and in October 2007 (remaining sites) (>12.0 mg gÀ1prot, $\mathrm{p}<0.05)$ and the minimum ( $<7 \mathrm{mg}$ gÀ1 prot) in all 4 sites. However, no significant differences exist between mean MT values for any of the sampled sites $(p>0.05)$. ALAD had the lowest levels in August 2007 (site 3), July 2008 (site 1 and 2) and October 2008 (site 4), with a minimum (0.1 ngPBG min mgÀ1prot) at site 1 (July 2008). The significantly higher ALAD activity (6.1e6.9 ngPBG min mgÀ1 prot, $p<0.05$ ) was in November 2007 (site 4) and April 2008 (site 1 and 3). However, significant differences between sites were only found for sites 2 and $3(p<0.05)$. AChE activity, typically inhibited by the presence of organophosphorus pesticides, carbamates and some metals (Lionetto et al., 2003), was generally lower in September 2007 in sites 1 and 4 and in September 2008 in sites 1 and $2(<1.1 \mathrm{nmol}$ min mgÀ 1 prot $)$ with the minimum at site $2(0.3 \mathrm{nmol}$ min mgà1 prot) (September 2008). These activities were significantly lower than the maximum levels (4.6e6.1 nmol min mgà1 prot) in April 2008 in the 4 sites. Nevertheless, no significant differences were found between sites ( $p>0.05)$. As for the damage biomarkers reflecting LPO and DNA damage, concentrations followed similar seasonal and spatial patterns. Significantly higher LPO values were in clams from sites 1 and 2 in August 2007 (536.1 and 464.1 nmol gÀ1 prot, respectively) and in sites 1 and 4 in November 2008 (428.2 and $409.7 \mathrm{nmol}$ gÀ1 prot, respectively) $(\mathrm{p}<0.05)$. DNA damage was significantly higher between July and September 2007 in all sites (max 11.1 arbitrary units) and in April 2008 (site 4,10.0 arbitrary units) $(\mathrm{p}<0.05)$. While no significant differences were found for DNA damage between sites ( $p>0.05$ ), for LPO a significant difference was found between sites 3 and $4(p<0.05)$. Vitellogenin-like protein concentrations, indirectly determined as alkali-labile phosphates (ALP), were separated by gender since increases in $\mathrm{Vg}$ like proteins in males and immature individuals are a better reflex of environmental exposure to endocrine disrupting compounds (EDCs) (Blaise et al.,1999; Matozzo et al., 2008). ALP levels in females and males were generally higher in summer but only significantly different at site 4 in July 2008 (>150 mg PO4 mgÀ1 Prot) $(\mathrm{p}<0.05)$. Significantly minimum concentrations were in winter ( $<30 \mathrm{mg}$ P04 mgà1 Prot) when only immature individuals were found $(\mathrm{p}<0.05)$. However, no significant differences exist between sites, neither for females, males or immature clams ( $p>0.05$ ).

3.5. Relationships between abiotic factors contaminants and biomarkers

Principal Component Analysis (PCA) was applied to environmental parameters contaminants and biomarkers by site and throughout the whole sampling period (mean values) to better understand the global results and depict the spatial association of sites (Fig. 2). PC1 accounts for $43 \%$ of the variance and shows that the most different sites were 2 and 3. PCA indicates site 2 as the most environmentally stressed and site 3 as the least impacted. Site 2 is associated with stronger biomarkers response (MT, ALAD, AChE, LPO and ALP in males) in clams, the highest mean concentrations of $\mathrm{Cd}, \mathrm{Cu}$ and $\mathrm{Pb}$, and 4 rings $\mathrm{PAHs}$, as well as environmental parameters (temperature, salinity, $\mathrm{pH}$ and dissolved oxygen). In opposition, clams from site 3 showed lower biomarkers response, despite having the highest mean concentrations of Zn, TBTs, total PAHs (mainly 5 p 6 rings) and Vg-like proteins in immature individuals. PC2 explains $35 \%$ of the variance and shows that clams from site 1 stand out with the highest ALP in females and immature individuals, and with the highest contribution of PAHs of low molecular weight ( 2 b 3 rings) and $\mathrm{Ni}$, as well as organic content in sediments. Lastly, PC3 explains $22 \%$ of the variance and differentiates site 4 that is associated with the lower mean temperature, concentration of PAHs, minimum DNA damage and Vg-like proteins in females and maximum condition index. However, it is associated with higher Vg-like proteins in males and immature clams, $\mathrm{Ni}$ and inhibition of AChE. 
Table 5

Condition Index and biomarkers levels (mean Æ standard deviation) ( $\mathrm{n} 1 / 45)$ in Ruditapes decussatus collected in the 4 sites in between July 2007 and December 2008 except for DNA damage where the standard error was used and $\mathrm{n} 1 / 410$ and $\mathrm{n} 1 / 4,15$ for ALP analysis.

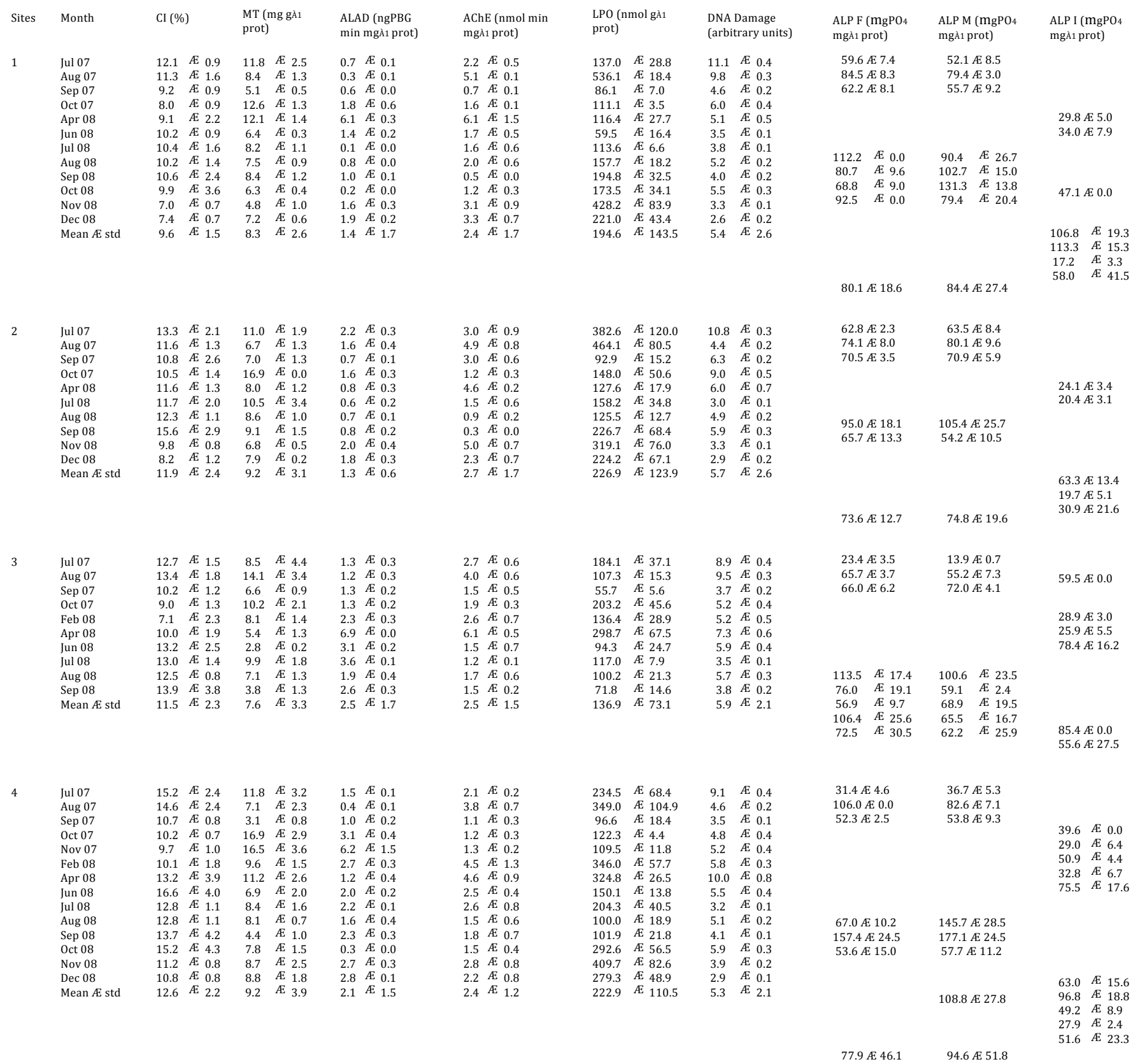

The influence of environmental variables was evident, as confirmed by the correlation analysis that revealed significant associations between biomarkers and environmental parameters but not with contaminants. ALAD activity was negatively related with temperature $(\mathrm{p}<0.05)$, AChE with salinity and dissolved oxygen $(\mathrm{p}<0.05)$ and LPO values with dissolved oxygen $(\mathrm{p}<0.05)$. DNA damage also showed a positive significant correlation with MT $(\mathrm{p}<0.05)$, suggesting that factors responsible for MT induction may promote DNA damage.

Data also revealed that biomarkers response between summer months in 2007 and 2008 were clearly different. To have an insight of the seasonal variability of data regarding the more stressful months (July to October) in the consecutive years (2007 and 2008), another PCA was applied to the monthly data (Fig. 3). PC1 is responsible for $36 \%$ of the variance and shows a clear separation between summer months of the different years (and also between sites). In 2007 the most important factors are the higher concentrations of MT, LPO and DNA damage coupled with higher levels of $\mathrm{Ni}$ and PAHs ( 5 b 6 rings), while in 2008 the dominant factors are ALP (males and females), $\mathrm{Pb}, \mathrm{Cu}$ e Zn and PAHs (2 b 3 rings), dissolved oxygen and inhibition of ALAD and AChE. PC2 accounts for $19 \%$ of the variance, showing a spatial separation of sites, with sites 1 and 2 closely related to higher biomarker responses (MT, LPO, DNA damage and ALP in males), total PAHs (mainly 2 p 3 and 4 rings) and Cd. On the other hand, sites 3 and 4 are closely related and more seasonally affected by environmental parameters (temperature, salinity, $\mathrm{pH}$ and dissolved oxygen), Ni, TBT and PAHs (5 p 6 rings). 


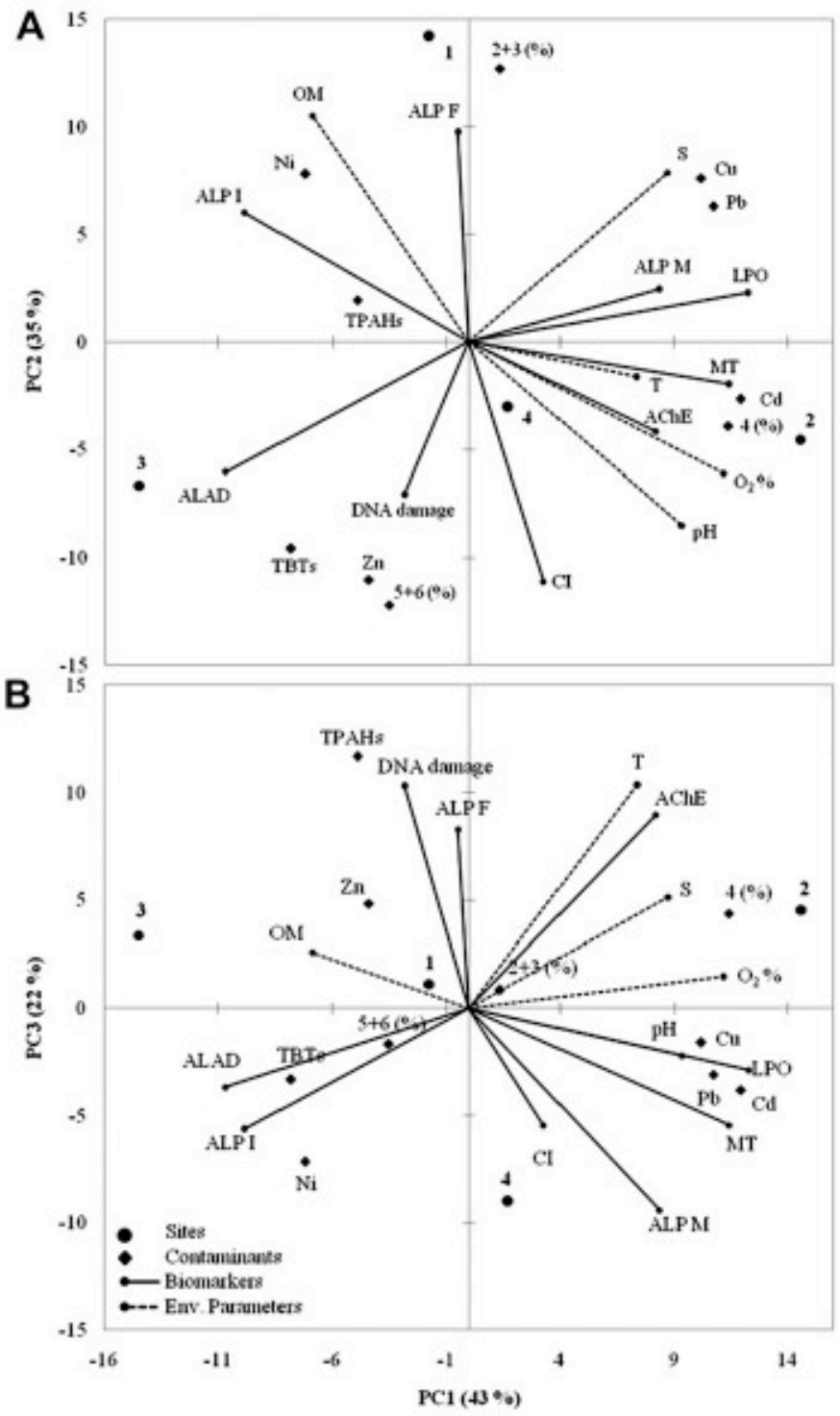

Fig. 2. Principal Component Analysis (PCA) of the biomarkers, contaminant levels (metals, TBT and PAHs) in the clam Ruditapes decussatus and environmental parameters from the 4 sites within the Ria Formosa lagoon between July 2007 and December 2008: A) PC1 vs PC2, B) PC1 vs PC3. T e temperature, Se salinity, Oz e oxygen, OM e organic matter, CI e condition index, Cd e cadmium, Cu e copper, Ni e nickel, Pb e lead, Zn e zinc, TBT e tributyltin, TPAHs e total polycyclic aromatic hydrocarbons, $\%$ PAH's with 2 p 3 rings, \% PAH's with 4 rings, \% PAH's with 5 b 6 rings, MT e metallothionein, ALAD e d-aminolevulinic acid dehydratase, AChE e acetylcholinesterase, 作 labile phosphates in males, ALP I e alkali-labile phosphates in immatures.

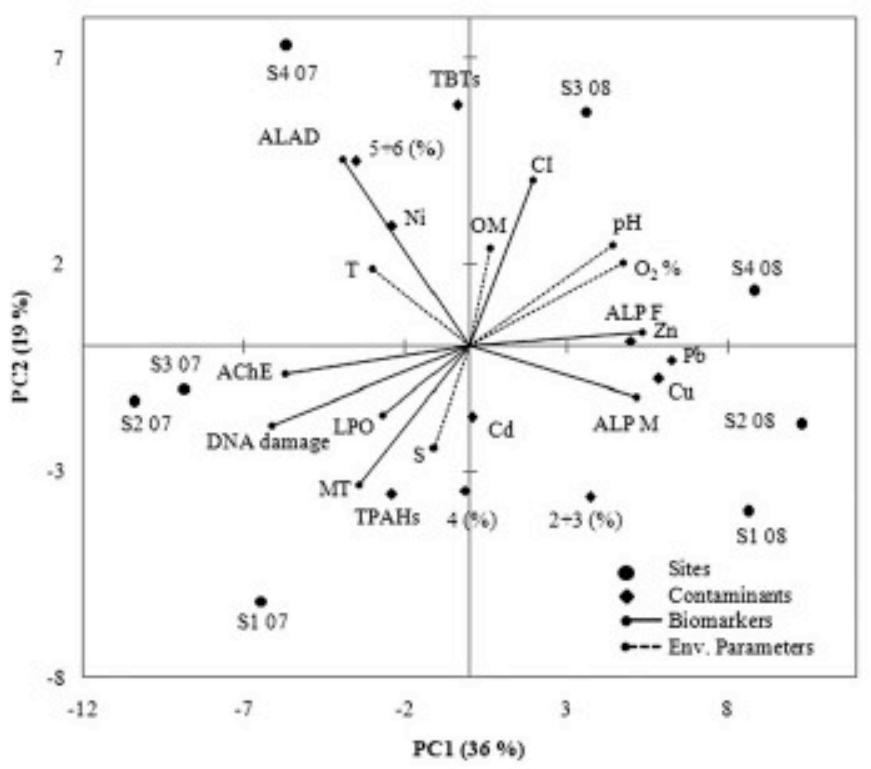

Fig. 3. Principal Component Analysis (PCA) of the biomarkers, contaminant levels (metals, TBT and PAHs) in the clam Ruditapes decussatus and environmental parame-
ters from the 4 sites (S1-S4) within the Ria Formosa lagoon in the summer months (July to October) separated by the consecutive years 2007 (07) and 2008 (08): PC1 vs PC2. T e temperature, $\mathrm{S}$ e salinity, $\mathrm{O}$ e oxygen, OM e organic matter, $\mathrm{CI}$ e condition index, Cd e cadmium, Cu e copper, Ni e nickel, Pb e lead, Zn e zinc, TBT e tributyltin TPAHs e total polycyclic aromatic hydrocarbons, \% PAH's with $2 \mathrm{p} 3$ rings, \% PAH's with 4 rings, \% PAH's with 5 p 6 rings, MT e metallothionein, ALAD e d-aminolevulinic acid dehydratase, AChE e acetylcholinesterase, LPO e lipid peroxidation, ALP F e alkalilabile phosphates in females, ALP M e alkali-labile phosphates in males, ALP I alkali-labile phosphates in immatures.

such as $\mathrm{Pb}, \mathrm{Cd}, \mathrm{Cu}$ and 4 rings PAHs (Table 3 ). In site 3 , considered the healthier, the main contribution comes from DNA damage, reflecting the presence of genotoxic compounds, despite of low effect when using the Mitchelmore et al. (1998) grade. Finally, in site 4 the greater influence is from Vg-like proteins in males, LPO and MT, indicating the presence of metals (e.g. $\mathrm{Cd}, \mathrm{Cu}, \mathrm{Pb}$ and $\mathrm{Ni}$; Table 3), EDCs and other compounds with the capacity to induce oxidative alterations.

Like for the IBR, the Health Status Index (HSI) integrates the information of the battery of biomarkers into a five-level status index. Both IBR and HSI were adapted to a colour code (Table 1), where the results are the same for both indices, with site 3 as the shellfish bed site where clams had a classification of A, corresponding to a colour code blue (Table 1), i.e. clams are healthy, while the others had a classification of $\mathrm{C}$, corresponding to a colour code yellow, i.e. clams are under medium stress.

\section{Discussion}

Regarding the accumulation of the analysed contaminants (Tables 3 and 4), the levels were not particularly high. Metal concentrations in clam tissues were in the same order of magnitude but lower than those previously reported for the Ria Formosa lagoon (Bebianno, 1995; Bebianno and Serafim, 2003; Cortesão et al., 1986; Serafim and Bebianno, 2001). This decrease in metal concentrations represents an improvement of the lagoon's water quality due to the enhancement of sewage treatment, better agricultural practices/ reduction of fertilizers and pesticides or more specifically in the case of lead due to the use of unleaded petrol. The highest TBT levels were in site 3 that is near the most important fishing harbour in the lagoon, which constitute a continuous TBT source, despite being forbidden since 2003. It is known that TBT is highly persistent in the 
A

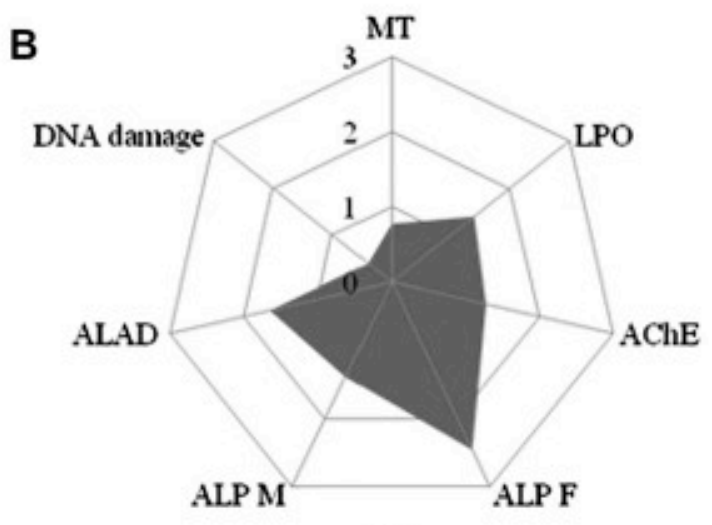

S3

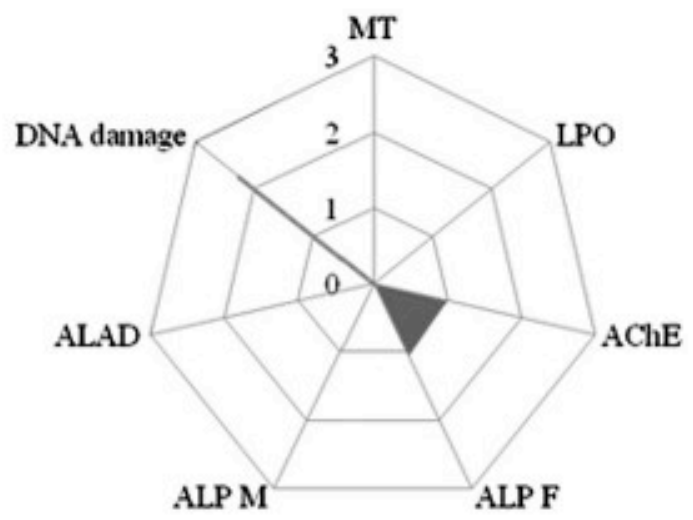

S1

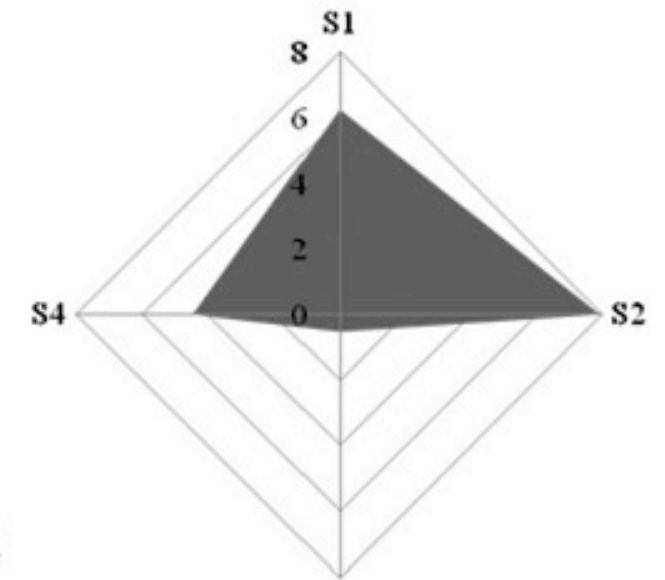

S2

S3 MT

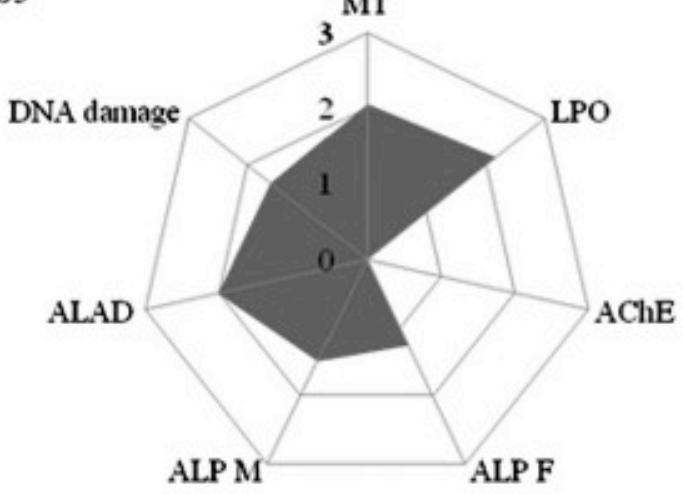

S4

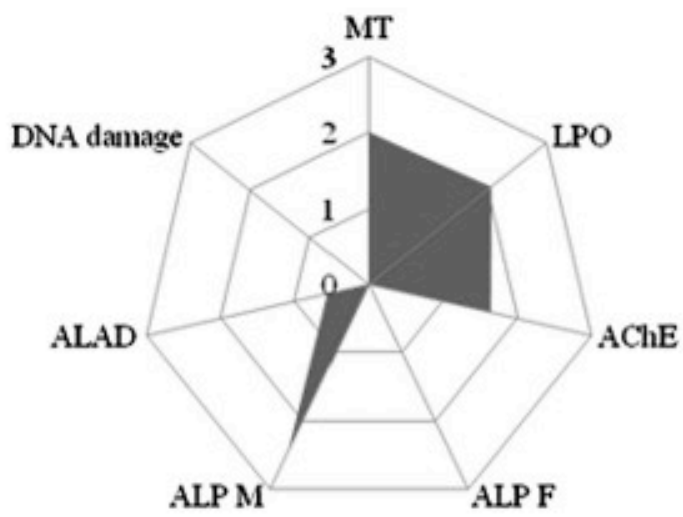

Fig. 4. Integrated Biomarkers Response (IBR) of Ruditapes decussatus collected in the Ria Formosa lagoon from July 2007 to December 2008: A) IBR for all 4 sites, B) Biomarkers star plots for each site. MT e metallothionein, LPO e lipid peroxidation, AChE e acetylcholinesterase, ALP F e alkali-labile phosphates in females, ALP M e alkali-labile phosphates in males, ALAD e d-aminolevulinic acid dehydratase.

environment; however, values are lower than in previous studies in shellfish beds from the same region (Coelho et al., 2002). In what concerns PAHs, the maximum concentration was also in site 3 with levels similar to others from the same ecosystem (Barreira et al. 2007a; Bebianno and Barreira, 2009).

Considering the biomarkers responses (Table 5), the range obtained is consistent with those in previous years in the Ria Formosa lagoon for MT (Bebianno and Serafim, 1998, 2003; Bebianno et al., 2000; Geret et al., 2003; Serafim and Bebianno, 2001), ALAD (data not published), AChE (data not published), LPO (Geret et al., 2003) and ALP (Pereira et al., in press). With respect to DNA damage, the only comparable data for bivalves from the Ria Formosa is with mussels Mytilus galloprovincialis (Almeida et al., 2011) that also points to similar seasonal fluctuations, with higher levels in summer. Applying the criteria established by Mitchelmore et al. (1998) (expressed in the same comparable unit) the DNA damage is minimal $(<10 \%)$, suggesting that the genotoxic potential of contaminants is small and can be considered baseline for future genotoxicity studies regarding this species in this ecosystem. However, no significant correlations were found between biomarkers and contaminants, supporting that contaminants are not particularly high to promote clear and strong biomarker responses and/or biomarkers are not responding specifically to these contaminants or even that other factors (like effects of abiotic environmental factors) can be affecting the high biomarker variability. In ecosystems where pollutants occur in mixtures, as in the 
Ria Formosa lagoon, results may not be easily understood and interactions among contaminants as well as with biological systems will influence the effect of other environmental compounds on the organisms response (Solé, 2000). Therefore, it is important to identify where synergistic, addition or antagonistic effects exist (including effects of abiotic environmental factors) that might complicate the general interpretation or mask the biomarkers responses (Cravo et al., 2009). This can explain the observations in site 3, regarding the highest values of TBT and PAHs that were not reflected in the biomarkers responses. In fact, it is known that TBT may affect the mixed function oxygenase (MFO) system that plays a key role in the metabolism of xenobiotics (e.g. PAHs), as well as endogenous compounds such as fatty acids and hormones. Therefore, any interaction with this system may have consequences on the animal's reproductive capacity and its ability to deal with other contaminants. Despite no determination of the MFO system components was conducted, TBT may interact with PAHs, providing lower biomarker response than what could be anticipated, due to a blockage response (Solé, 2000). Inhibition of the MFO components may also have consequences on oxyradical production and oxidative damage protection failure because these enzymes are involved in the redox cycling of some organic xenobiotics (Solé, 2000). The significance of these changes in the physiology of the organisms and evidence of these alterations in the field needs further research (Morcillo et al., 1998). Other biomarkers, such as AChE activity in bivalve molluscs, can also be inhibited by the presence of contaminants in complex mixtures (Dellali et al., 2001) as in the present study. Metals, among other compounds, may also decrease AChE activity, and in this study, this biomarker had minimum values in site 2 , where $\mathrm{Cd}, \mathrm{Cu}$ and $\mathrm{Pb}$ concentrations (and \% of 4 rings PAHs) were highest. Moreover, ALAD activity varied negatively with temperature and AChE with salinity and dissolved oxygen, and this has already been pointed out by others authors in different bivalve species (Dellali et al. 2001; Pfeifer et al., 2005). It is also known that AChE is directly affected by temperature (Dellali et al., 2001; Leiniö and Lehtonen, 2005; Pfeifer et al., 2005). In the present work, no significant correlation was found between this biomarker and temperature ( $p>0.05$ ), but the lowest mean AChE activity was at site 4, where the mean temperature was also lowest (Table 2). This site is relatively close to the main inlet, where the presence of pesticides is not relevant.

A very important aspect related to the use of a multibiomarker approach in risk assessment is the need of having a detailed knowledge of basal biomarkers response and of its seasonal variation to distinguish pollution induced effects from those induced by the natural biological cycle of clams, including the reproductive cycle and spawning period (Bocchetti and Regoli, 2006; Bocchetti et al., 2008). A CI decreasing pattern was detected in summer months (Table 5), particularly from August to November, which may be due to loss of weight/body mass associated with the period of spawning (accentuated in August and September for this species). Accordingly, seasonal variation of CI may be associated to fluctuations in the reproductive cycle of clams. In R. decussatus, spawning coincides with summer, when stressful environmental parameters were more notorious. In ALP responses, this seasonality is more evident since its levels follow the same trend of the gametogenic cycle in females with mature individuals having naturally higher ALP concentrations (Blaise et al. 1999; Matozzo et al., 2008). However, this does not explain the higher Vg-like protein concentrations in males since only during the resting stages of gonadal development would ALP levels in females be similar to males (Blaise et al. 1999; Matozzo et al., 2008; Porte et al. 2006) which is indicative of the presence of EDCs. On the other hand, different studies have pointed out that vitellogenin is also an immune-relevant molecule with a potential role in defence reactions, possessing antibacterial and hemagglutinating activities (Shi et al., 2006; Tong et al., 2010; Zhang et al., 2005). This can also be an explanation to the presence of $\mathrm{Vg}$ in adult males and to the similarity of ALP levels between males and females, although suggesting that the organism's defence system is responsive to external agents more critical during summer.

The interpretation of data provided by such a multibiomarker approach is difficult without an integrated overview that globally assesses the potential influence of contaminants and environmental conditions in each site. Analysing individual information regarding biomarkers response is rather limited. Therefore, to overcome this drawback and integrate the data as a whole, a PCA was conducted. In ecosystems like the Ria Formosa lagoon, where contamination is not particularly high, seasonal factors such as severe environmental parameters (Table 2) have an important effect on biomarkers response (Leiniö and Lehtonen, 2005; Orbea et al., 2002), as reflected by the correlation between biomarkers and environmental conditions for the global studied period (Fig. 2). The high temporal variability of biomarkers, with higher responses in summer can thus be strengthened by the influence of environmental parameters (e.g. higher seawater temperature, solar irradiance, oxygen decrease) that could induce higher physiological stress as already observed for other bivalve species (Andrès et al., 1999; Baudrimont et al., 1997; Bocchetti and Regoli, 2006; Bocchetti et al., 2008; Leiniö and Lehtonen, 2005). Additionally, oxidative damage such as lipid peroxidation or DNA damage can be triggered and produce detrimental effects on the physiological status of clams (Bocchetti and Regoli, 2006; Bocchetti et al., 2008; Sobral and Widdows, 1997). The PCA for the overall data (Fig. 2) revealed that the site with worst conditions for clams is site 2 , while in site 3 clams were least impacted. Between the most stressful summer months in both years, biomarkers response changed spatially and between years (Fig. 3), reflecting the change in the environmental conditions. In this period, temperatures exceed $25 \mathrm{C}$ (higher solar radiance), higher salinities and organic matter in the sediment may lead to a decrease of oxygen $(<70 \%)$ and $\mathrm{pH}$ in water and interstitial water in the sediments that may also affect the biomarkers response and undermine clam's health. In fact, LPO was negatively associated to dissolved oxygen, suggesting that a decrease of water oxygenation promoted an increase of LPO. In site 1 , water oxygen saturation reached 50 and $67 \%$, lower than the minimum percentage allowed for shellfish waters $(<70 \%)$ by the Portuguese National Legislation (DR, 1998), compromising the metabolic activity of bivalves. On the other hand, the maximum values ( $>120 \%)$ between July and September in all sites may also be of concern. An excess of micro/macroalgae during the day also increase the oxygen consumption during the night (respiration process), leading to a drastic decrease of dissolved oxygen. This is aggravated in summer months when the bivalve's metabolic and excretion rates are elevated due to the water temperature, and lead to an increase of organic matter degradation. This will favour the consumption of oxygen either in the water or in interstitial water of the sediment due to organic matter accumulation, leading to a $\mathrm{pH}$ decrease.

Besides the use of PCA to understand results, improvement is needed to interpret the variation among the biomarkers used for environmental diagnosis. Multivariate methods such as biomarker indices can integrate the biomarker information and categorize sites according to pollutant-induced changes in the health status of the organisms. These simple biomarker-based indices were applied to rank sampling sites and reflect contamination gradients, providing decision-support tools to evaluate the ecosystem "health". As stated before, it is very important to bear in mind the magnitude and potential interaction between contaminants, as 
well as the influence of environmental and physiological stress (and spawning period) that mask or influence some of the biomarkers responses, and influence the result of the applied IBR and HSI indices. Indices that aggregate all the biomarker information are suitable and useful decision-support tools for environmental managers and provide a general idea of the health status of the ecosystem. The results of both indices corroborated the PCA, pointing site 3 as the site were clams had the best status (healthy) and sites 2, 1 and 4 where the clams are under higher stress (medium stress). However, in studies of environmental assessment to avoid a misinterpretation of data the application of indices based only on the biomarkers response must be used with caution and should be interpreted along with the chemical data, environmental factors and if possible consider the reproductive cycle or other parameters reflecting physiological stress.

In conclusion, stressful conditions were registered mainly in the summer season and contaminant concentrations were not considered particularly high when compared with other studies, although enough to discriminate sites. Even between the consecutive summers, environmental conditions and biomarkers responded distinctively providing a spatial and temporal differentiation. Nevertheless, it would be desirable that all sites presented a ranking similar to site 3 , that is, healthy or low stressed, as required by the European Water Framework directive (Directive, $2000 / 60 /$ EC).

\section{Acknowledgements}

This study was financially supported by the Olhão Municipality (Portugal).

\section{References}

Almeida, C., Pereira, C., Gomes, T., Bebianno, M.J., Cravo, A., 2011. DNA damage a a biomarker of genotoxic contamination in Mytilus galloprovincialis from the South coast of Portugal. Journal of Environmental Monitoring 13, 2559e2567. Andrès, S., Baudrimont, M., Lapaquellerie, Y., Ribeyre, F., Maillet, N., Layouche, C. Boudou, A., 1999. Field transplantation of the freshwater bivalve Corbicula minea along a polymetallic contamination gradient (rver Lot, France): 1. Geochemical characteristics of the sampling sites and cadmim and zinc bio$2462 \mathrm{e} 2471$

Barreira, L.A., Bebianno, M.J., Mudge, S.M., 2005. Relationship between PCBs in suspended and settled sediments from a coastal lagoon. Ciencias Marinas 31 (1B), $179 \mathrm{e} 195$

Barreira, L.A., Mudge, S.M., Bebianno, M.J., 2007a. Polycyclic aromatic hydrocarbon in clams Ruditapes decussatus (Linnaeus, 1758). Journal of Environmental Monitoring 9, 187e198.

Barreira, L.A., Mudge, S.M., Bebianno, M.J., 2007b. Concentrations and sources of polycyclic aromatic hydrocarbons in sediments from the Ria Formosa lagoon. Environmental Forensics 8, 231e243.

Baudrimont, M., Lemaire-Gony, S., Ribeyre, F., Métivaud, J., Boudou, A., 1997. Seasonal variation of metallothionein concentrations in the asiatic clam (Corbicula fluminea). Comparative Biochemistry and Physiology C 118 (3), $361 \mathrm{e} 367$

Bebianno, M.J., 1995. Effects of pollutants in the Ria Formosa lagoon, Portugal. The Science of the Total Environment 171, 107e115.

Bebianno, M.J., Langston, W.J., 1989. Quantification of metallothioneins in marine invertebrates using differential pulse polarography. Portugaliae Electrochimica Acta 7,511 e524.

Bebianno, M.J., Barreira, L.A., 2009. Polycyclic aromatic hydrocarbons concentrations and biomarker responses in the clam Ruditapes decussatus transplanted in the Ria Formosa lagoon. Ecotoxicology and Environmental Safety 72 $1849 \mathrm{e} 1860$

Bebianno, M.J., Serafim, M.A., 1998. Comparison of metallothionein induction on response to cadmium in the gills of the bivalve molluscs Mytilus galloprovincialis and Ruditapes decussatus. The Science of the Total Environment 214, $123 \mathrm{e} 131$.

Bebianno, M.J., Serafim, A., 2003. Variation of metal and metallothionein concentrations in a natural population of Ruditapes decussatus. Archives of Environmental Contamination and Toxicology 44, 53e66.

Bebianno, M.J., Serafim, M.A., Simes, D., 2000. Metallothionein in the clam Ruditapes decussatus: an overview. Analusis 28 (5), 386e 390
Bebianno, M.J., Géret, F., Hoarau, P., Serafim, M.A., Coelho, M.R., Gnassia e Barelli, M., Roméo, M., 2004. Biomarkers in Ruditapes decussatus: a potenti

Bebianno, M.J., Lopes, B., Guerra L. Hoarau, P., Ferreira, A.M., 2007. Glutathione Stranferases and cytochrome $\mathrm{P} 450$ activities in Mytilus galloprovincialis from the South coast of Portugal: effect of abiotic factors. Environmental International $33,550 \mathrm{e} 558$.

Beliaeff, B., Burgeot, T., 2002. Integrated biomarker response: a useful tool for ecological risk assessment. Environmental Toxicology and Chemistry 21 (6) $1316 \mathrm{e} 1322$

Berlin, A., Schaller, K.N., 1974. European standardized method for determination of delta-ALAD activity in blood. Zeitschrift fur Klinische Chemie und Klinische

Blaise, C., Gagné, F., Pellerin, J., Hansen, P.D., 1999. Determination of vitellogenin-like properties in Mya arenaria hemolymph (Saguenay Fjord, Canada): a potential biomarker for endocrine disruption. Envionmental Toxicology 14, $455 \mathrm{e} 465$. Boccheti, R., Regoli, F., 206. Seasonal variability of oxidative biomarkers, lysosomal parameters, metallothionsins and peroxis oxid 913 e921.

Bocchetti, R., Lamberti, C.V., Pisanelli, B., Razzetti, E.M., Maggi, C., Catalano, B., Sesta, G., Martuccio, G., Gabellini, M., Regoli, F., 2008. Seasonal variations of exposure biomarkers, oxidative stress responses and cell damage in the clams, Tapes philippinarum, and mussels, Mytilus galloprovincialis from Adriatic sea. Marine Environmental Research 66, 24e26.

Bradford, M., 1976. A rapid and Sensitive method for the quantitation of microgram quantities of protein utilizing the principle of protein-dye binding. Analytical Biochemistry 72, 248e254.

Bryan, G.W., Gibbs, P. Hummerstone, L.G., Burt, G.R., 1986. The decline of the gastropod Nucella lapillus around the south-west England: evidence for the effect of tributyltin from antifouling paints. Journal of the Marine Biological Association of the United Kingdom 66, 611e640.

Caetano, M., Vale, C., Bebianno, M., 2002. Distribution of Fe, Mn, Cu and Cd in upper sediments and sediment-trap material of the Ria Formosa (Portugal). Journal of Coastal Research 36, 118e123.

Cajaraville, M.P., Bebianno, M.J., Blasco, J., Porte, C., Sarasquete, C., Viarengo, A., 2000. The use of biomarkers to assess the impact f pollution in coastal environments of the Iberian Peninsula: a practical approach. The Science of the Total Environment 247, 295e311.

Coelho, M.R., Bebianno, M.J., Langston, W.J., 2002. Organotin levels in the Ria Formosa lagoon. Portugal. Applied Organometallic Chemistry 16, 384e390. Company, R., Serafim, A., Lopes, B., Cravo, A., Shepherd, T.J., Pearson, G., Bebianno, M.J., 2008. Using biochemical and isotope geochemistry to understand the environmental and public health implications of lead pollution in the lower Guadiana River, Iberia: a freshwater bivalve study. Science of the Total Environment 405, 109e119.

Cortesão, C., Mendes, R., Vale, C., 1986. Metais pesados em bivalves e sedimentos na Ria Formosa, Algarve. Boletim do Instituto Nacional da Investigação das Pescas $14,3 \mathrm{e} 28$.

Cravo, A., Lopes, B., Serafim, A., Company, R., Barreira, L., Gomes, T., Bebianno, M.J., 2009. A multibiomarker approach in Mytilus galloprovincialis to assess environmental quality. Journal of Environmental Monitoring 11, 1673e1686. Dagnino, A., Allen, J.I., Moore, M.N., Broeg, K., Canesi, L., Viarengo, A., 2007. Development of an expert system for the integration of biomarker responses in mussels into an animal health index. Biomarkers 12 (2), 155e172.

Dellali, M., Gnassia-Barelli, M., Romeo, M., Aissa, P., 2001. The use of acetylcholinesterase activity in Ruditapes decussatus and Mytilus galloprovincialis in the biomonitoring of Bizerta lagoon. Comparative Biochemistry and Physiology Part C $130,227 \mathrm{e} 235$

Díez, S., Lacorte, S., Vianna, P., Barceló, D., Bayona, J.M., 2005. Survey of organotin compounds in rivers and coastal environments in Portugal 1999-2000. Environmental Pollution 136, 525e536.

Directive 2000/60/EC of the European Parliament and of the Council of 23 October 2000 establishing a framework for Community action in the field of water policy. O) L $327,22.12 .2000,1 \mathrm{e} 73$.

DR (Diario da Republica), 1998. Normas, critérios e objectivos de qualidade com a finalidade de proteger o meio aquático e melhorar a qualidade das águas em fuça dos seus principis usos Decto Ellman, G.L., Courtney, K.O., Anders, V., Featherstone, R.M., 1961. A new and rapi macology 7, 88e95.

Erdelmeier, I., Gerard-Monnier, D., Yadan, J.C., Acudiere, J., 1998. Reactions of Nmethyl-2-phenylindole with molondialdehyde a 4 - hydroxyakenas. Mechnistic aspects of the colorimetric assay of lipid peroxidation Chemals. Mechain Toxicology 11,1184 e1194.

Geret F, Serafim, A, Bebianno M 2003. Antioxidant enzyme activities, metalEcotoxicology 12,417e426.

Langston, W.J., Burt, G., Zhou, M., 1987. Tin and organotin in water, sediment and benthic organisms of Poole Harbour. Marine Pollution Bulletin 18,634e639. inio, S, Lehtonen, K. K, 2005. Seasonal variability in biomarkers in the bivalves Mytilus edulis and Macoma balthica from the northern Baltic Sea. Comparative Biochemistry and Physiology Part C 140, 408e421.

Lionetto, M.G., Caricato, R., Giordano, M.E., Pascariello, M.F., Marinosci, L Schettino, T., 2003. Integrated use of biomarkers (acetylcholinesterase and 
antioxidant enzymes activities) in Mytilus galloprovincialis and Mullus barbatus in an Italian coastal marine area. Marine Pollution Bulletin 46, 324e330. Lowry, O.H., Rosenbrough, N..., Farr, A.L., Randall, R.J., 1951. Protein measurement with folin phenol reagent. Journal of Biological Chemistry 193, 265e275.

Maria, V.L., Santos, M.A., Bebianno, M.J., 2009. Biomarkers of damage and protection in Mytilus galloprovincialis cross transplanted in Ria Formosa Lagoon (Portugal). Ecotoxicology 18, 1018e1028.

Matozzo, V., Gagné, F., Marin, M.G., Ricciardi, F., Blaise, C., 2008. Vitellogenin as a biomarker of exposure to estrogenic compounds in aquatic invertebrates: a review. Environmental International 34, 531e 54

Mitchelmore, C.L., Birmelin, C., Livingstone, D.R., Chipman, J.K., 1998. Detection of DNA strand breaks in isolated mussel (Mytilus edulis L.) digestive gland cells using the "Comet" assay. Ecotoxicology and Environmental Safety 41, 51e58. Monserrat, J.M., Martínez, P.E., Geracitano, L.A., Amado, L.L., Martins, C.M.G., Pinho, G.L.L., Chaves, I.S., Ferreira-Cravo, M., Ventura-Lima, J., Bianchini, A., 2007. Pollution biomarkers in estuarine animals: critical review and new perspectives. Comparative Biochemistry and Physiology, Part C 146, 221e234. Morcillo, Y., Ronis, M..J.., Porte, C., 1998. Effects of tributyltin on the phase 1 testosterone metabolism and steroid titres of the clam Ruditapes decussatus.

Moschino, V., Marin, M.G., 2006. Seasonal changes in physiological responses and valuation of "well-being" in the venus clam Chamelea gallina from the Chart A 145,

Nasci, C., Da Ros, L., Nesto, N., Sperni, L., Passarini, F., Pavoni, B., 2000. Biochemical and histochemical responses to environmental contaminants in clam, Tapes philippinarum, transplanted to different polluted areas of Venice Lagoon, Italy. Marine Environmental Research 50, 425e430.

Orbea, A., Ortiz-Zarragoitia, M., Solé, M., Porte, C., Cajaraville, M.P., 2002. Antioxidant enzymes and peroxisome proliferation in relation to contaminant body burdens of PAHS and PCBs in bivalve molluscs crabs and fish from Urbaida Plentzia estuaries (Bay of Biscay). Aquatic Toxicology 58, 75e98.

Pereira, C., Gomes, T., Cardoso, C., Almeida, A. C., Araújo, O., Bebianno, M. J., Cravo, A. in press. Interspecific variability of endocrine disruption and oxidative stress in two bivalve species from the Ria Formosa Lagoon (South Coast of Portugal). Scientia Marina.

Pfeifer, S., Schiedek, D., Dippner, J.W., 2005. Effect of temperature and salinity on acetylcholinesterase activity, a common pollution biomarker, in Mytilus sp. from the south-western Baltic Sea. Journal of Experimental Marine Biology and Ecology $320,93 \mathrm{e} 103$

Porte, C., Solé, M., Borghi, V., Martinez, M., Chamorro, J., Torreblanca, A., Ortiz, M., Orbea, A., Soto, M., Cajaraville, M.P., 2001. Chemical, biochemical and cellular responses in the digestive gland of the mussel Mytilus galloprovincialis from the Spanish Mediterranean coast. Biomarkers 6 (5), 335e350.

Porte, C., Janer, G., Lorusso, L.C., Ortiz-Zarragoitia, M., Cajaraville, M.P., Fosse, M.C., Canesi, L., 2006. Endocrine disruptors in marine organisms: approaches and perspectives. Comparative Biochemistry and Physiology Part C 143, 303e31

Ribeiro, J., Monteiro, C.C., Monteiro, P., Bentes, L., Coelho, R., Gonçalves, J.M.S., Lino, P.G., Erzini, K., 2008. Long-term changes in fish communities of the Ria ormosa coastal lagoon (southern Portugal) based on two studies made 20 years apart. Estuarine. Coastal and Shelf Science 76, 57 e68,

Serafim, M.A., Bebianno, M.J., 2001. Variation of metallothionein and metal concentrations in the digestive gland of the clam Ruditapes decussatus: sex an seasonal effects. Environmental Toxicology and Chemistry 20 (3), 544e552. hhi, X., Zhang, S., Pang, Q., 2006. Vitellogenin is a novel player in defense reactions. Fish \& Shellish Immunology 20, $769 \mathrm{e} 772$.

Singh, N.P., McCoy, M.T., Tice, R.R., Schneider, E.L., 1988. A simple technique for quantitation of low levels of DNA damage in individual cells. Experimental Cell Research 175 (1), 184e191.

Sobral, P., Widdows, J., 1997. Effects of elevated temperatures on the scope for growth and resistance to air exposure of the clam Ruditapes decussatus (L.) .

Solé, M., 2000. Effects of tributyltin on the MFO system of the clam Ruditapes Decussatus: a laboratory and field aproach. Comparative Biochemistry and

Physiology Part C 125, 93e101.
Steinert, S.A., Montee, R.S., Sastre, M.P., 1998. Influence of sunlight on DNA damage mussels exposed to polycyclic aromatic hydrocarbons. Marine Environmental

Tong, Z., Li, L., Pawar, R., Zhang, S., 2010. Vitellogenin is an acute phase protein with bacterial-binding and inhibiting activities. Immunobiology 215, 898e 902 . biomarkers in biomonitoring: a 2-tier approach assessing the level of pollutantinduced stress syndrome in sentinel organisms. Comparative Biochemistry and Physiology, Part C 146, 281e 300 .

Zhang, S., Sun, Y., Pang, Q., Shi, X., 2005. Hemagglutinating and antibacterial activities of vitellogenin. Fish \& Shellfish Immunology 19, 93e95. 